\title{
JORNALISMO, DEMOCRACIA E GOLPE: A CRISE DE 1955 NAS PÁGINAS DO CORREIO DA MANHÃ E DE O ESTADO DE S. PAULO
}

\author{
Flávia Biroli
}

\section{RESUMO}

Neste trabalho discutimos aspectos do debate político que se deu na segunda metade dos anos 1950, representativo de um conjunto de práticas que ultrapassam aquele momento da história brasileira; concentramo-nos, sobretudo, na crise em torno da eleição e da posse de Juscelino Kubitschek e João Goulart, ocorrida em 1955, visualizada a partir de textos publicados nos jornais Correio da Manhã $e$ O Estado de S. Paulo, que ocuparam lugares opostos durante a crise. Interessa-nos aqui explicitar elementos de continuidade no período 1946-1964, entre o que destacamos práticas por meio das quais se evidenciou um desprezo pela política em seus elementos de confronto e luta, acompanhado de uma difundida descrença nos processos eleitorais e na capacidade de discernimento da população. Ressaltamos, sobretudo, duas temáticas: 1) o papel das massas na política, com sua correspondente crítica às elites e ao "atual estado" da democracia no país, vista como falha elou incompleta e 2) as funções atribuídas ao jornalismo diante desse diagnóstico recorrente. Nossas considerações acerca dos posicionamentos dos dois jornais inseremse nessa problemática, que impõe considerações sobre as superposições e entrelaçamentos entre liberalismo e autoritarismo, democracia e golpe.

PALAVRAS-CHAVE: jornalismo; democracia; golpe; liberalismo; autoritarismo; Brasil anos 1950.

\section{INTRODUÇÃO}

Neste texto trabalhamos alguns aspectos do debate suscitado pelas eleições presidenciais de 1955, em que foram vencedores Juscelino Kubitschek, candidato pelo Partido Social Democrático (PSD) e que governaria o Brasil entre 1956 e 1961, e João Goulart, candidato pelo Partido Trabalhista Brasileiro (PTB), eleito vice-Presidente em 1955 e também nas eleições posteriores, de 1960, vindo a ocupar a presidência da República em 1961, em decorrência da renúncia de Jânio Quadros. O questionamento dos resultados das urnas por parte da oposição ligada à União Democrática Nacional (UDN), assim como os episódios dele resultantes, compõem a situação de crise política para a qual nos voltamos.

Chamamos a atenção para o fato de que se destacaram, no processo eleitoral de 1955, candidatos que representavam, do ponto de vista da oposição, a continuidade do poder e das práticas políticas vinculadas ao varguismo. Foram eles, como nas eleições presidenciais anteriores, de 1945 e 1950, os vencedores nas urnas, em prejuízo dos candidatos vinculados à UDN, partido criado em abril de 1945. Não poderíamos deixar de ressaltar também o fato de que essa oposição udenista, que buscou durante toda sua existência identificar-se com ideais políticos liberais, em contraposição às práticas autoritárias atribuídas a Vargas e seus aliados, recorreu inúmeras vezes durante o período de vigência da democracia eleitoral no Brasil (19451964) a tentativas de deslegitimar o curso normal das eleições e, em última instância, ao golpe, na medida em que as urnas não lhe abriam o caminho para o poder governamental, especialmente para a Presidência da República.

Não se trata aqui de colocar em destaque o liberalismo no Brasil para afirmar a existência de contradições ou ambigüidades que o caracterizariam, mas de apontar para discursos e práticas que compuseram confrontos políticos relevantes, constituindo, portanto, os sentidos e limites do processo democrático no Brasil daqueles anos. Acreditamos que essa abordagem permite relacionar problemas históricos singulares a práticas de maior duração e permanência na história política no país, em especial no que se refere às tradições do pensamento político e aos discursos que 
projetam identidades e conferem legitimidade à atuação política da imprensa.

No que diz respeito à problemática central à discussão aqui encaminhada, a crise de 1955 não foi uma exceção. Nela estiveram, de um lado, parte considerável dos auto-proclamados liberais, contestando os resultados das urnas e procurando dar amparo e legitimidade a uma possível ação golpista; de outro, os herdeiros do ex-ditador e seus aliados, procurando garantir que o curso da democracia representativa não se alterasse e que a posse dos eleitos fosse realizada, o que se tornou possível por meio do contra-golpe (ou golpe, dependendo da posição assumida no decurso da luta política) desfechado pelo General Henrique Teixeira Lott em 11 de novembro de 1955.

As forças em confronto durante a crise de 1955 estão incluídas na discussão feita por Wanderley Guilherme dos Santos (1978), em ensaio bastante conhecido no qual o autor confere as denominações de "liberalismo doutrinário" e "autoritarismo instrumental" às duas tradições políticas que, segundo ele, teriam tido até então maior permanência na história brasileira.

$\mathrm{O}$ autoritarismo instrumental caracterizar-se-ia, basicamente, pelo recurso ao Estado autoritário, politicamente centralizado, como forma para atingir-se a organização política desejada, permitindo a realização de um acerto entre a esfera jurídico-política e a formação histórica da nacionalidade (cujo descompasso vinha sendo diagnosticado por vários autores e atribuído, com frequiência, à sedução das elites brasileiras pelo liberalismo). Não descartaria, no entanto, a possibilidade de que por meios autoritários fossem construídas as condições vistas como necessárias para uma organização de tipo democrático, ainda que bastante restrita. Um exemplo característico dessa tradição encontra-se na obra de Oliveira Vianna, publicada especialmente nas décadas de 1930 e 1940.

O "liberalismo doutrinário", como definido por Santos, pode, por sua vez, ser exemplificado, durante a primeira República, pela práxis política de Rui Barbosa. Diz respeito ao modo de inserção dos ideais liberais na luta política no país, em especial a partir de meados do século XIX, tendo como um de seus traços principais a crença de que a formulação e a execução de regras legais adequadas engendrariam as reformas políticosociais necessárias. Estas, de acordo com os aspectos predominantes nesse pensamento até a década de 1930, poderiam ser viabilizadas por meios liberais, entre eles a pressão da opinião pública e resultados eleitorais que significassem a desaprovação de práticas vigentes, como o coronelismo (ou a política de clãs, na expressão utilizada por Oliveira Vianna), o nepotismo e a corrupção.

A Constituição de 1937 abriu espaço para parte das demandas explicitadas pelo autoritarismo no Brasil da época. Durante o período de duração do regime que aí se iniciou, parece-nos possível vislumbrar as forças políticas em confronto segundo a denominação de Santos, que acabamos de expor. Para compor um mapa simplista, de um lado esteve o poder constituído em um Estado centralizado que recorreu explicitamente à violência e à coação, procurando concentrar e homogeneizar as disposições do agir político; de outro, a oposição que, especialmente no início da década de 1940, fixou sua bandeira na retomada dos direitos políticos e, com eles, no restabelecimento da dinâmica partidária ${ }^{1}$.

Com a derrocada da ditadura em 1945 e a polarização das forças políticas entre o varguismo e o anti-varguismo, representados pelos partidos de maior expressão da época (de um lado, PSD e PTB; de outro, UDN), colocamo-nos diante de um emaranhado que suscita questões que nos parecem relevantes à reflexão acerca da práxis liberal no Brasil, para utilizarmos a expressão que dá título ao ensaio de Wanderley Guilherme dos Santos a que nos referimos. Retomada a dinâmica partidária, elaborada uma nova Constituição (1946), os "liberais doutrinários", agora representados pela UDN, seriam, como dissemos, consecutivas vezes derrotados nas urnas, especialmente nos pleitos em que estiveram em

1 Entre os jornais com que trabalhamos neste texto, $O$ Estado de S. Paulo destaca em suas memórias institucionais a oposição à ditadura do Estado Novo e a intervenção sofrida pelo jornal entre 1940 e 1945 . Procura, inclusive, construir um paralelo entre essa oposição, seguida de intervenção, e a censura sofrida durante a ditadura do pós-1964, esvaziando as particularidades de sua atuação e constituindo um arco temporal que contribuiria para identificar esse jornal com a defesa da democracia no país. Conferir, como exemplo do trabalho de fixação dessa memória, o caderno comemorativo dos 125 anos do jornal, publicado em 2000 e, nele, o texto da contra-capa do caderno, intitulado "O Estadão faz 125 anos, mas só conta 120. Erro de cálculo? Não, intervenção mesmo". 
jogo cargos executivos. Entre essas derrotas, incluímos a frustração maior: Vargas, o ditador uma vez alijado do poder, voltaria à presidência, poucos anos depois, "nos braços do povo", isto é, consagrado pelas urnas nas eleições de 1950 .

Continuando com Santos, no pós-1945, a decepção do liberalismo anti-varguista estava na percepção sustentada à época de que "os partidos que Vargas planejou e criou (PSD e PTB) e a sociedade que legou às novas gerações interagiam de tal maneira que somente os políticos que se submetessem à corrupção poderiam ter possibilidade de vencer" (idem, p. 99). Não haveria, assim, possibilidade de sucesso naquele sistema político, isto é, segundo aquelas regras. "Desde que faltava legitimidade ao sistema, era perfeitamente correto, e dentro da mais pura tradição liberal, tentar derrubá-lo adotando inclusive meios violentos, se necessário fosse" (ibidem).

Na hipótese levantada pelo autor sobre a política do período e, de maneira mais ampla, sobre as relações entre autoritarismo e liberalismo, "admitida a não legitimidade de qualquer sistema, os grupos políticos, inclusive os liberais, doutrinários ou não, passam a agir da mesma forma, isto é, tentando destruí-lo através de quaisquer meios disponíveis" (ibidem). Assim caminharia a UDN, a passos largos que a levariam à participação no golpe civil-militar de 1964, que instauraria, por sua vez, um governo de predominância militar que marginalizaria e mesmo forçaria ao exílio alguns dos liberais conservadores que foram fundamentais para a subversão do regime anterior (democrático-liberal) e para a interrupção da presidência do herdeiro político de Vargas, João Goulart (identificado, pela oposição, com as tradições autoritárias do varguismo).

Levantamos aqui uma outra hipótese, com a qual trabalharemos. No que se refere às tradições políticas no Brasil, e às linguagens que vêm assumindo em sua expressão no período para o nos qual temos voltado ${ }^{2}$, um outro traço identifica parte considerável do pensamento das elites e das práticas políticas predominantes no cenário nacional de então, que precedeu o golpe de 1964:

2 As discussões aqui desenvolvidas baseiam-se, em grande parte, nas pesquisas desenvolvidas para a tese de doutorado da autora, defendida em junho de 2003 (BIROLI, 2003). o desprezo pela política em seus elementos de confronto e luta, acompanhado de uma difundida descrença nos processos eleitorais e na capacidade de discernimento da população em geral. Se esses elementos são característicos do "autoritarismo instrumental", tal como definido por Santos, e do autoritarismo em sentido amplo, eles foram marcantes também na prática política das elites liberais - prática que envolve, na perspectiva que assumimos, a expressão discursiva de posicionamentos, com intenções persuasivas ou em busca de identidades e contrastes constitutivos da luta política.

Os aspectos discursivos, em especial, que sustentaram essas práticas de negação da política, segundo a hipótese levantada, podem ser pensados e analisados também em sua constante atualização por jornais de destaque na imprensa do eixo RioSão Paulo naquele período. Para a exposição de aspectos do debate suscitado pelas eleições de 1955, com ênfase para o desenvolvimento da hipótese anunciada, trabalharemos, portanto, com artigos, editoriais e notícias publicados em dois dos jornais brasileiros de maior circulação no período, Correio da Manhã e $O$ Estado de S. Paulo (OESP), que ocuparam lugares antagônicos durante a crise em torno da candidatura, eleição e posse de Kubitschek e Goulart.

O Estado de S. Paulo, da família Mesquita, vinculado à UDN e ferrenho opositor de Vargas, especialmente após a intervenção sofrida pelo jornal durante a ditadura do Estado Novo, contestou a candidatura, a eleição e, posteriormente, a posse dos candidatos. O Correio da Manhã, de Paulo Bittencourt, que fizera coro com o Estado na oposição a Vargas e às práticas políticas com ele identificadas, especialmente durante a crise de 1954, que culminou no suicídio de Vargas, apoiaria, em 1955, a candidatura de Juscelino Kubitschek, de cujo governo participaria o então Diretor de Redação do jornal, Álvaro Lins. Um outro ponto de vinculação entre o governo e o jornal foi o jornalista, poeta e industrial Augusto Frederico Schmidt, principal eminência parda do governo $\mathrm{JK}$, articulista do Correio e autor de uma série de artigos em defesa da candidatura JK-Jango a que faremos referência mais adiante.

O liberal conservador $O$ Estado de S. Paulo e o então juscelinista Correio da Manhã voltariam a coincidir, de modo geral, alguns anos depois, ao assumirem posições semelhantes nos meses que 
antecederam o golpe de 1964. No início daquele ano, enquanto o Estado, como em 1955, participava ativamente das articulações golpistas, em que teve destaque a presença de Júlio de Mesquita Filho ${ }^{3}$, o Correio publicava seus famosos editoriais intitulados "Basta!" e "Fora!", pedindo a interrupção do mandato de Goulart ${ }^{4}$.

Nossa opção pelo material publicado nesses jornais decorre, portanto, do fato de terem sustentado posições diversas durante a crise de 1955, mas também do fato de considerarmos que foram, naquele momento, interlocutores importantes, agentes que mediaram (e matizaram, de acordo com seus interesses e percepções) as perspectivas em confronto. Nas palavras de Alzira Alves de Abreu e Fernando Lattman-Weltman (1994, p. 31), em estudo voltado para a atuação da grande imprensa brasileira na crise de 1954, $O$ Estado de S. Paulo e Correio da Manhã estiveram entre "[...] os jornais que, em suma, por sua própria história e razão de ser, melhor espelhavam $\mathrm{e}$, por isso, intermediavam o(s) discurso(s) das elites".

Neste artigo desenvolvemos a discussão proposta a partir de duas temáticas. A primeira refere-se à participação das massas na política, sempre vinculada à crítica às elites, permitindonos inclusive situar melhor as oposições e sobreposições entre as perspectivas de "varguistas" e "anti-varguistas" ou, no caso específico da crise de 1955, entre juscelinistas e udenistas, tais como estiveram presentes nos jornais aqui trabalhados. A segunda temática, por sua vez, refere-se às funções atribuídas à imprensa e à atividade jornalística diante do duplo diagnóstico do descompasso entre elites e realidade e da incompletude e fraqueza da democracia no país.

\footnotetext{
3 Segundo Bernardo Kucinski (1975), Júlio de Mesquita Filho esteve envolvido em reuniões para a articulação do golpe desde o início de 1962, sediadas no próprio jornal, em que se discutiram as linhas gerais que deveria assumir o novo regime. Maria Vitória Benevides (1981) relata, também, que já em 1962 Júlio de Mesquita Filho propunha aos líderes militares que se opunham à permanência de Jango no governo um "Roteiro da revolução". O namoro entre $O E S P$ e o regime militar do pós-1964 passaria por diversos conflitos a partir de 1965, com um afastamento maior a partir do governo Médici.

4 Partes desses editoriais foram publicados por Jefferson de Andrade (1991).
}

\section{ELITES INCAPAZES E MASSAS AMORAIS O DIAGNÓSTICO DO DESCOMPASSO}

Para dar início à primeira temática, expomos parte de um artigo publicado por Augusto Frederico Schmidt no Correio da Manhã, no dia anterior às eleições de 3 de outubro de 1955, em que explicitava ainda uma vez sua opção pela candidatura de Kubitschek: "O país está cansado de política, está cansado de esperar que se resolvam as divergências, as lutas, as incompatibilidades e as dissonâncias da política. O país está cansado da pressão que sofreu durante dez meses em que não se fez mais nada senão esperar acontecimentos, lutas, durante um certo momento o golpe e em seguida, à guisa de consolo - ai de nós! -, a guerra civil. O país está cansado de polêmicas, de dilacerações, e precisa trabalhar.

[...] O cidadão que for eleito Presidente da República [...], além de todos os problemas administrativos, terá o dever indeclinável de combater o estado de intoxicação de más idéias em que se encontra o povo brasileiro, enganado e desviado pelas suas elites. Elites que não são elites a rigor, porque nada sabem ou conhecem da realidade. Nada será conseguido neste país se não conseguir-se a transformação do espírito brasileiro em alguma coisa de mais largo, de mais compreensivo, de mais sério, de mais contemporâneo e mais próximo do que deve ser, para o nosso bem, o verdadeiro espírito nacional" (SCHMIDT, 1955c, p. 2).

Insistindo um pouco nos termos, o cansaço da política é, portanto, cansaço das divergências, dissonâncias, polêmicas. A elas seria preciso dar um "basta" para que se pudesse trabalhar. Para que se pudesse instaurar esse "tempo novo" de trabalho, e não de política, seria preciso considerar dois aspectos: os excessos da política, implicando uma desqualificação da política, vinculada a atraso e desordem, e o descompasso entre elites e realidade, que impediria, também, o curso do desenvolvimento ${ }^{5}$

5 Nos dois casos, mas especialmente no que se refere à desqualificação da política, encontramos uma oposição entre desordem e ordem, em que o segundo dos dois termos aparece vinculado a uma noção supostamente não-política de desenvolvimento. A relação entre desenvolvimento e ordem é enfatizada por Miriam Limoeiro Cardoso (1978) como central ao discurso desenvolvimentista de Kubitschek em seu período de governo. 
A tematização desses aspectos foi comum à série de artigos publicada por Schmidt no Correio da Manhã no ano de 1955. Nela, algumas formulações foram exemplares, como esta, em que o poeta reforçaria seu desprezo pela política, legada sempre ao plano do que é desnecessário, ou artificial: "uma décima parte da energia humana despendida na política ajudaria de forma importante a enfrentar as crises reais do Brasil" (SCHMIDT, 1955d, p. 2). Outros artigos, por sua vez, exemplificariam fortemente a temática do descompasso entre as elites e a realidade, como se pode ler a seguir: "Saudades de um Brasil em que já se tenha operado a readaptação das suas elites à realidade nacional. Em que os homens capazes de formular as coisas não as mostrem com as raízes desentranhadas, expostas ao vento, sem outra função a não ser viravoltear em torno de abstrações, dançando com idéias abolidas, ultrapassadas" (SCHMIDT, 1955b, p. 2).

Schmidt referia-se especificamente aos políticos udenistas e seus aliados, em formulações que ecoam aquelas do autoritarismo dos anos 20 e 30 em sua crítica à política dos "bacharéis". Caracterizava-os como "homens de bravura, polemistas, esgrimistas da palavra", porém alheios aos dramas vividos pelo Brasil. Não correspondiam, dizia, ao momento atravessado pelo país: "Se podem alguns ler autores clássicos ou dar uma interpretação correta a um texto de lei, não são na verdade contemporâneos do Brasil que precisa realizar-se para sobreviver" (SCHMIDT, 1955a, p. 2).

Lembramos que Augusto Frederico Schmidt, nessa mesma série de textos - em consonância com a linha do jornal em que os publicava -, defendia a candidatura de JK e o curso normal das eleições em contraposição às articulações golpistas lideradas por políticos vinculados à UDN, ainda que o fizesse em meio a idéias que marcaram no Brasil justamente tradições autoritárias que afirmaram repetidas vezes a incompatibilidade entre a democracia representativa, o voto direto e o estado presente (e histórico, em uma referência à formação ou às raízes) do Brasil. Essas tradições autoritárias não apenas consideraram dissidências e divergências como forças negativas na construção política da nacionalidade, como repetidas vezes consideraram que as falhas ou incompatibilidades supostas da democracia com o Brasil deviam-se à ausência de elites, acompanhada da ausência de eleitores no sentido liberal, isto é, de cidadãos capable of law $^{6}$ (para recorrer a um dos autores clássicos do liberalismo, John Locke).

Lembramos, ainda, para expor o emaranhado diante do qual nos situamos, que enquanto Schmidt, que se poderia inserir na tradição do "autoritarismo instrumental" por diversos aspectos de sua biografia, defendia o curso normal das eleições, o contraponto a seu posicionamento circunstancial era feito justamente pelos políticos que Wanderley Guilherme dos Santos incluiu entre os "liberais doutrinários" (compondo-se especialmente em torno da UDN, do Partido Libertador (PL) e do Partido de Representação Popular (PRP)). Não consideramos, no entanto, que a defesa dos procedimentos eleitorais e as discussões acerca da democracia e do desenvolvimento que deveriam "fazer-se reais" com Juscelino no governo, nos termos em que foram formuladas por Schmidt nos textos publicados no Correio, sejam exceções à biografia repleta de práticas que denotam suas visões elitistas e autoritárias, marcadas pelo catolicismo em suas expressões mais conservadoras no Brasil ${ }^{7}$.

O diagnóstico do descompasso entre elites e realidade, entre letra e real, assim como o anúncio de que novos tempos nasceriam desse ajuste, do prometido encontro entre a política e o "Brasil real" (que, no caso, efetuar-se-ia por meio da liderança de Juscelino Kubitschek e de sua orientação para

\footnotetext{
6 “Capazes da lei”, em inglês (nota do revisor).
}

7 Como o próprio Correio da Manhã, Schmidt seria, mais adiante, um defensor da derrocada do então Presidente João Goulart e do golpe de 1964 (sobre esse assunto, cf. SCHMIDT, 1964). Essa defesa conferiu as tonalidades finais à biografia do poeta e industrial, morto em 1965, que foi ligado a Jackson Figueiredo, Plínio Salgado e Alceu Amoroso Lima. Um dos principais articuladores da Operação Pan-Americana durante o governo Kubitschek, Schmidt aparece, na narrativa autobiográfica do escritor Autran Dourado (um dos muitos escritores mineiros que estiveram vinculados ao governo Kubitschek), em cenas de amizade e admiração por Francisco Campos, jurista que foi o principal responsável pela elaboração da Constituição de 1937, e em cenas de amizade e cumplicidade com aquele que seria o primeiro dos Presidentes após o golpe civilmilitar de 1964, Castelo Branco. Outros aspectos de sua biografia são o envolvimento com o movimento integralista, nos anos 1930, e a participação ativa no IPES (Instituto de Pesquisas e Estudos Superiores) e na edição e circulação de folhetos e outros escritos anticomunistas que fizeram parte da atmosfera de preparação do golpe de 1964. 
o desenvolvimento do país), é um diagnóstico de longa tradição no pensamento político no Brasil, assim como a promessa a ele correspondente, sempre reiterada, da chegada de novos tempos que realizariam o esperado encontro - promessa que fez parte da linguagem dos debates políticos em 1930, 1937, 1955, 1964...

Durante a crise de 1955 , essa percepção do descompasso entre letra e real fez parte também dos argumentos opostos, que aqui extraímos, em especial, de textos publicados no jornal $O$ Estado de S. Paulo. O que justificaria, do ponto de vista de $O$ Estado de $S$. Paulo e da UDN, a interrupção do curso normal das eleições e, em última instância, o golpe?

A vitória nas urnas de candidatos ligados ao varguismo foi vista, repetidamente, como um resultado da mistificação e do engodo realizados pela ditadura do Estado Novo e pelos 15 anos de poder ditatorial de Getúlio Vargas. Nessa percepção, as massas iletradas e supostamente incapazes de autonomia foram vinculadas à elite corrupta, ao coronelismo, assim como às práticas políticas populistas atribuídas a Vargas para arrebanhar simpatizantes nos centros urbanos, que incluíam, da perspectiva udenista, as leis trabalhistas e especialmente o modelo de sindicalização adotado a partir dos anos 1930. Haveria, assim, um descompasso primeiro e central entre a sistemática política democrático-liberal - que inclui a dinâmica representativa e implicava a assunção de que os eleitores estavam aptos a escolher e, como tal, a constituir maiorias votantes - e a realidade de um país em que a maioria teria sido "contaminada" e "iludida" pelo varguismo. Dessa perspectiva, se o país expressava uma consonância com a política varguista (determinando o insucesso, nas urnas, dos liberais conservadores udenistas), isso significava não uma escolha consciente ou uma aprovação em algum nível dos eleitores, mas uma incapacidade de escolha de eleitores iletrados e/ou iludidos.

São muitos os exemplos em $O$ Estado de $S$. Paulo, materializados em posicionamentos coincidentes, em geral, com aqueles assumidos pela UDN durante a crise de 1955. Passemos a alguns deles.

O noticiário político de 5 de novembro de 1955 traria, em destaque, uma referência ao discurso feito na Câmara dos Deputados no dia anterior pelo então Deputado Federal e vice-Presidente da UDN, Adauto Lúcio Cardoso. Respondendo à afirmação do Deputado Federal pelo PSD José Maria Alkmin, que viria a ser Ministro da Fazenda durante o governo de Kubitschek, de que "os propósitos moralizadores da UDN não encontra[va]m receptividade na massa" (NA CÂMARA DOS DEPUTADOS, 1955, p. 3), o Deputado udenista discorreu sobre o "amoralismo das massas despreparadas" no Brasil, procurando caracterizar o que seria um comportamento permanente dos eleitores no país - o de escolher sempre os piores candidatos. Às palavras de Cardoso, o jornal $O$ Estado de S. Paulo adicionaria que, para além do despreparo, seria preciso pensar na preparação das massas, pelo varguismo e por meio do silenciamento da imprensa, para que chegasse, então, "a esse estado lamentável de falta de lucidez" (ibidem).

Formulações semelhantes estiveram presentes em um texto de Wilson Martins, articulista do Estado e um dos fundadores da UDN do Mato Grosso do Sul, comentando o livro, então recémlançado, A crise da democracia e a reforma eleitoral (1955), de autoria de Ruy Bloem, jornalista de renome na época, que trabalhava para a empresa Folha, também em São Paulo. O articulista expressou concordâncias e discordâncias em relação aos argumentos de Bloem. Entre as principais discordâncias incluímos a afirmação de que o problema estava não exatamente no Código Eleitoral de 1950, como teria afirmado o jornalista, mas na crise da democracia, de que resultariam os defeitos daquele. Nesse ponto e nos que seguem, Wilson Martins refere-se a um livro de sua autoria, Introdução à democracia brasileira (1951), em que, segundo ele mesmo definiu no artigo publicado em $O$ Estado de S. Paulo, defendeu a idéia de que não existe um mal intrínseco às formas de organização política, aos regimes, com ênfase para o regime democrático; o problema estaria na aplicação e na conformação desses regimes às sociedades: "a conclusão inevitável é a de que 'cada povo tem o regime que merece', neste sentido de que cada um o conforma e pratica na linha de sua própria mentalidade, do seu próprio avanço espiritual, do seu efetivo grau de civilização" (A CRISE DA DEMOCRACIA, 1955, p. 8). O eleitor brasileiro tinha, nessa perspectiva, um código eleitoral que correspondia a seu estágio de desenvolvimento político: voto personalista, em busca de líderes iluminados ou providenciais, de que Vargas teria sido o maior exemplo. Martins concordava com Bloem no sentido de que seria 
necessário um código que atenuasse o personalismo na política brasileira, por meio, entre outras coisas, da instituição do voto de legenda, procurando também corrigir problemas na representação dos partidos no Legislativo.

O jornalista e político udenista (e, mais uma vez, vinculado ao principal partido representativo do chamado "liberalismo doutrinário"), no entanto, localizou o problema, acima de tudo, na amplitude do sufrágio. Para Martins, o sufrágio universal só poderia responder efetivamente à "essência da democracia" quando fundado em um discernimento apurado do eleitor, o que não correspondia, em suas palavras, ao Brasil daqueles anos. Ao sufrágio deveria corresponder um certo estágio de civilização: "Praticá-lo como no Brasil dos nossos dias, entregando as mais fundamentais decisões de sua vida pública a eleitores que, na sua grande maioria, são incapazes de bem avaliar a importância e o alcance do ato político representado pelo voto, é transformar o regime democrático em puro regime totalitário" (MARTINS, 1955, p. 8).

Mais uma vez, colocamo-nos diante de um emaranhado considerável: essa percepção mobilizada por Wilson Martins foi predominante nas formulações conservadoras de intelectuais como Oliveira Vianna e Azevedo Amaral, ao constatarem, no presente em que produziram suas análises, a impossibilidade do exercício democrático, uma vez que - recorrendo a Vianna - os laços clânicos e a ausência de sentido de nacionalidade nas massas votantes determinariam, para as eleições, um conteúdo ficcional. Seu prognóstico, daí resultante, dizia respeito à necessidade de um Estado forte, autoritário, de certa forma materializado pelo golpe e pela Constituição de 1937, instaurando o regime a que se oporiam, justamente, os liberais que orbitaram em torno da UDN no período posterior.

A elaboração de Wilson Martins vincula-se, assim, a um modo de interpretar e atribuir sentido à história, conferindo ao Brasil, ao mesmo tempo, um duplo mal: ausência de raízes desejáveis, que favorecessem o desenvolvimento político democrático, e presença de características culturais daí derivadas, fixando-nos, naquele momento, em um estágio anterior ao da correspondência entre instituições políticas adequadas ao desenvolvimento da democracia, povo-cidadão e elites competentes para a superação - das próprias raízes.
Voltando ainda ao jornalista e político udenista Wilson Martins, os regimes totalitários foram assim descritos: "[...] regimes de massas, em que apenas conta o número dos aderentes, não a sua qualidade; as democracias são regimes de povos, isto é, regimes próprios de países em que a massa, por suas condições de educação e de discernimento, acresceu à sua natural expressão numérica as virtudes inestimáveis da qualidade" (ibidem).

A interpretação já destacada de que o Brasil encontrava-se em estágio civilizatório anterior àquele que seria característico das democracias, possibilitando-as, relaciona-se à distinção entre "massas" e "povos" que compõe o argumento do jornalista. No espaço-tempo que separaria essas duas formas de organização, estariam fatores como "mentalidade", "civilização", "temperamento", mas, especialmente, como indica o último trecho que citamos, "educação". Se considerados verossímeis e plausíveis, os argumentos de Wilson Martins em $O$ Estado de $S$. Paulo podem fundar conclusões como a de que os regimes autoritários, centralizados, seriam mais compatíveis ao país; de que os regimes centralizados (e excludentes) não seriam senão respostas às condições históricas das sociedades e, ainda, de que, para que o Brasil pudesse contar com um regime de tipo democrático (mesmo que em uma concepção de democracia restrita ao critério da representatividade e do sufrágio universal) seria necessário, primeiro, transformar as "massas" em "povo" ou, nos termos de Gabriel Tarde, transformar as "massas" em "públicos" - uma necessidade que deveria, na perspectiva de Martins, ser levada adiante pelas elites, com atenção especial para a missão pedagógica e civilizadora de que seria portadora a imprensa, permitindo que ele mesmo, como jornalista, configurasse-se como sujeito à parte ao diagnosticar os problemas e prescrever as estratégias de ação diante da grande tarefa.

Com isso, passamos à segunda temática deste artigo, referente à função do jornalismo diante dos diagnósticos expostos acima, que vêm fundando leituras reiteradas e insistentes da realidade histórica brasileira.

\section{DEMOCRACIA E JORNALISMO: DAS FALHAS EDAAÇÃO CORRETIVA}

A distinção elaborada por Gabriel Tarde (1992), entre massas e públicos, realiza-se de acordo com uma percepção histórico-cronológica que atribui a um dos termos, massas, o estatuto de inferio- 
ridade e anterioridade e, ao outro, "públicos", o de superioridade e contemporaneidade. O principal acontecimento a que o autor relaciona o advento dos públicos é o surgimento da imprensa e, nela, o do jornalismo. A paixão pela atualidade, um dos principais efeitos desse fenômeno moderno, permitiria laços ao mesmo tempo poderosos e mais voláteis, que não implicariam, como nas massas, contato físico e presença corpórea, mas que teriam sua força na simultaneidade da leitura das folhas e na homogeneização cada vez maior dos interesses. Se as multidões não desapareceram com o advento dos públicos (podendo ser, até mesmo, "resíduos" desses últimos, como teria ocorrido na Revolução Francesa, segundo Tarde); se os públicos mantiveram, ainda que em intensidade bastante reduzida, características definidoras das multidões, o autor não deixaria de afirmar o caráter "mais refletido e calculado" dos públicos em relação às massas.

O texto de Tarde apresenta uma tensão que nos interessa explicitar, entre a percepção de que a formação dos públicos, correlata à da imprensa, significava a constituição de agrupamentos mais intelectualizados e ponderados, e uma outra percepção, sempre presente: a do risco da homogeneização e do nivelamento democrático, enfatizado pelos estudos de Alexis de Tocqueville sobre os Estados Unidos ${ }^{8}$. Para a presente discussão, essa tensão é de grande relevância na medida em que atribui ao jornalismo a ambigüidade de ser atividade de "esclarecimento" (que transforma massas em públicos) e de "nivelamento", contribuindo para a superioridade do numérico, aquela mesma que caracterizaria,

\footnotetext{
8 Tocqueville (1998) considera, no entanto, que o advento de sociedades baseadas em maior igualdade (o exemplo para o autor foram os Estados Unidos da primeira metade do século XIX), ainda que significasse também uma vulgarização maior dos usos e das idéias e um nivelamento dos intelectos e da cultura, era a melhor opção diante de dois pólos: democracia ou tirania. Um dos pontos destacados pelo autor a respeito dos Estados Unidos foram os recursos colocados em ação, na disposição política da sociedade e em seu aparato jurídico, para evitar, dentro do possível, o risco sempre presente da "tirania das massas", em formulação freqüente no pensamento liberal do século XIX. Tocqueville é particularmente interessante nesse sentido porque ancora suas análises na idéia de que o fluxo histórico levaria, inevitavelmente, a sociedades de tipo democrático. Seria melhor, então, aceitar esse dado e trabalhar para obter, sobre ele, um controle que lhe permitisse demarcar os limites.
}

para Wilson Martins, os regimes totalitários $e$ as democracias (lembramos que o predomínio do maior número foi definido no texto do jornalista e político udenista como "ranço inseparável e paradoxal do regime democrático" (MARTINS, 1955 , p. 8)).

Nas palavras de Tarde, no ensaio "A opinião e a conversação", publicado pela primeira vez em 1899 , “[...] nem para o recrutamento dos representantes, nem para sua atuação, a lei do número era concebida ou concebível antes do desabrochar da imprensa e da nacionalização da opinião. Depois, nenhuma outra lei parece ser imaginável; a despeito de todos os perigos e todos os absurdos que implica, o sufrágio universal impõe-se pouco a pouco por toda parte, na expectativa de que ele próprio tenha a sabedoria de reformar-se e, a despeito de objeções evidentes, admite-se que todo o mundo deve curvar-se perante a mais grave decisão votada pela metade das vozes mais uma.

O sufrágio universal e a onipotência das maiorias parlamentares só foram possíveis pela ação prolongada e acumulada da imprensa, condição sine qua non de uma grande democracia niveladora" (TARDE, 1992a, p. 91).

No texto publicado em $O$ Estado de $S$. Paulo de que falávamos, a tensão desloca-se um pouco em relação à perspectiva que apontamos no texto de Tarde. A ameaça da regra do "maior número" viria justamente do fato de que, no Brasil dos anos 1950, uma transformação como aquela de que falava o autor francês nos momentos finais do século XIX não teria sido ainda possível. Os problemas atribuídos por uma série de interpretações a nossas raízes históricas 9 , associados à atuação do Estado Novo - imprensa censurada, manutenção dos costumes e mentalidades daí resultantes, restringindo a capacidade dos eleitores -, comporiam os fatores devido aos quais não teria chegado o país ao "nível de qualidade indispensável às instituições democráticas", impossibilitando fundar a democracia "na representação das opiniões".

\footnotetext{
9 Sobre a presença ampla dessa percepção - ausência de raízes adequadas e um desenvolvimento falho ou desencontrado - nas tradições interpretativas da história brasileira, especialmente a partir das primeiras décadas do século XX, cf. Bresciani (2001).
} 
Essa forma de negação da legitimidade da política democrática representativa no Brasil, ou, repetindo termos antes utilizados, dos elementos conflitivos como característicos da política, esteve presente, como indicamos de maneira sucinta, nos dois jornais citados, em sua atuação entre as forças políticas que se enfrentaram durante a crise de 1955. Esteve presente, ainda, em textos publicados por autores que não poderiam ser alinhados ao varguismo ou ao udenismo, como Mário Pedrosa, intelectual de filiação trotskista que escrevia uma coluna fixa em $O$ Estado de $S$. Paulo na época ${ }^{10}$, indicando uma difusão desses argumentos e imagens que ultrapassa a polaridade destacada.

Em muitos textos, essa negação vinculou-se a um elemento bastante presente no jornalismo e que constitui sua identidade e, de certo modo, seu lugar de poder nas sociedades contemporâneas: referimo-nos ao recurso à construção de um lugar especial, de neutralidade e desinteresse, para a imprensa, como parte da estratégia de atribuição de verdade e autoridade aos argumentos ali presentes. Citamos, aqui, alguns exemplos indicativos, restritos mas que explicitam sentidos em continuidade com aqueles presentes em uma série de textos escritos por jornalistas durante os anos 1950 e início dos 1960. Ainda com Wilson Martins, no artigo antes citado: "Note-se que nem de longe exprimo preferências pessoais e, ao contrário, sou o primeiro a lamentar profundamente esse estado de coisas; mas creio que o grande e mais irrecusável dever dos publicistas é, antes de mais nada, o de efetuar o exato e desapaixonado diagnóstico das situações" (MARTINS, 1955, p. 8).

Em $O$ Estado de S. Paulo, a campanha próUDN incitaria as seguintes palavras: "Jornal de oposição, isto é, jornal que não se enfeuda nem se enfeudou nunca a grupos, partidos, ou governos - a independência de que legitimamente nos orgulhamos dá-nos força moral para aconselhar a quem nos lê a que perfilhe como sua a causa de moralização, ordem e de respeito encabeçada pela UDN" (O NOSSO CONSELHO, 1955, p. 3).

$\mathrm{Ou}$, como afirmaria o Correio mais enfaticamente em setembro do ano seguinte, ao opor-

10 Sobre os artigos publicados por Mário Pedrosa no Correio da Manhã, conferir a tese de doutorado da autora (BIROLI, 2003). se ao projeto de lei de imprensa apresentado então pelo governo Kubitschek e que não chegaria a ser votado: "O Judiciário nada pode contra os tanques. A maioria do Legislativo - esta já sabemos que recebe instruções do $\mathrm{I}^{\circ}$ Exército. Na defesa do regime, está a imprensa. É o único poder que se opõe ao grupo militar que se agiganta para encher o lugar do Presidente que se nanifica. É preciso sufocar a imprensa para que o regime democrático no Brasil fique convertido num corpo sem substância: só casca e aparência. [...] A farsa democrática poderia continuar a ser representada. Não haveria mais quem denunciasse a farsa e os farsantes" (EDITORIAL, 1956, p. 6).

Essa última formulação é bastante representativa do argumento freqüente que vinculava uma suposta degeneração dos poderes republicanos a uma responsabilidade de vigilância e denúncia atribuída ao jornalismo. Daí então a projeção para a imprensa de um "lugar" de credibilidade que se ancoraria em um discurso que procurava esvaziar suas condições efetivas de inserção nas sociedades contemporâneas (como empresas capitalistas, vinculadas a interesses particulares e peculiares e, portanto, marcadamente parciais - ainda que, no caso de certas empresas, sem vínculos partidários fortes ou estáveis): algo como deter para si uma função política sem ser parte da política, por mais paradoxal que isso possa ser. Deter, portanto, uma função que confere credibilidade por basearse em uma suposta exterioridade diante de uma política insistentemente caracterizada como caótica, desordenada (porque conflituosa), corrupta e cega (porque expressão de elites e massas votantes com tais características).

A missão de que se investiria a imprensa consistiria, assim, em múltiplas funções - e dissimulações.

Dentro de perspectivas de matriz liberal, pautadas por uma suposta vinculação entre democracia, liberdade de imprensa e liberdade de opinião, poderíamos dizer, correndo o risco de repetir um pouco o que se propôs no parágrafo anterior, que se procurou sustentar a visão de que jornais e jornalistas destacavam-se do emaranhado de interesses característicos da política, agindo, portanto, de uma perspectiva, se não neutra, pelo menos superior e desinteressada.

Foram repetidos, ainda, argumentos que implicam a visão de que a política partidária, representante de interesses parciais, jogava segundo regras distintas daquelas a que atenderia o 
jornalismo - este sim capaz de representar os "interesses gerais" e, como tal, escapar da vinculação entre conflito e desordem, entre parcialidade e ameaça à estabilidade.

Um outro ponto ainda merece destaque. Os argumentos, intrinsecamente relacionados aos anteriores, procuraram sustentar a seguinte percepção: uma vez suposta a incompletude ou ineficiência da política democrática representativa (indo da suposição da ignorância das massas e do desconhecimento das reais necessidades do país pelas elites à crítica ao regime pela incapacidade de representação do todo, pelas práticas de corrupção e pelos interesses mesquinhos que constituiriam sua realidade presente e efetiva, em virtude das marcas deixadas pelo varguismo), caberia à imprensa um papel essencial, isto é, o de, por meio do esclarecimento e da vigilância, denunciar as limitações do processo democrático e, ao mesmo tempo, aprimorá-lo, completando-o - ainda que, em alguns momentos, isso tenha significado o recurso ao golpe.

Houve, assim, um paralelo entre a frustração udenista com os resultados das urnas, após a derrocada do Estado Novo e a retomada do sistema democrático de inspiração liberal, e a frustração da maior parte dos grandes jornais (aí incluídos proprietários, dirigentes e parte dos cronistas e jornalistas em atividade) que, auto-investidos das imagens que apontamos, estiveram ao lado da oposição udenista na derrocada da ditadura que terminou em 1945 e em grande parte dos pleitos que se seguiram a ela.

Se a relevância do jornalismo foi atribuída à sua possibilidade de representar e orientar a opinião pública, como lidar com o fato de que o alcance dessa orientação fosse tão restrito, redundando em diversos fracassos eleitorais, não apenas de políticos udenistas, mas de parte das diretrizes políticas defendidas por parcela considerável da grande imprensa? A resposta histórica dessa imprensa na época, e de muitos jornalistas nela empregados, parece ter sido o apoio (ou participação intensa na articulação, em alguns casos) às soluções golpistas. Uma interessante mistura que fez que democracia e golpe compusessem um mesmo movimento de tessitura da história.

Nesse sentido, um texto editorial publicado em $O$ Estado de S. Paulo afirmava a existência de limites sutis entre a democracia e a tirania, clamando, por isso mesmo, para o direito de "legítima defesa" do regime, que não poderia entregar-se ao suicídio. Nesse caso, a afirmação dizia respeito à proteção do regime em relação a um dos inimigos mais constantemente projetados e superdimensionados durante o período: o comunismo. Dependendo da força do ataque, dizia o editorial, deveria ser determinada a força da reação. Cito parte do texto: "O fato revela até que ponto a democracia admite a liberdade" (o fato aqui é o de que os cidadãos considerados comunistas, tratados como "elementos" ou "farsantes", pudessem recorrer à Justiça ao serem considerados, pela própria Justiça, inaptos para concorrer a cargos públicos, fato considerado pelo jornal como um indício da flexibilidade do regime democrático no Brasil); "Esse pois é o regime que nos convém, que haverá de perdurar enquanto os que exercem a autoridade não traírem o povo, ou enquanto existir a vigilância democrática" (VIGILÂNCIA DEMOCRÁTICA, 1955, p. 8) ${ }^{11}$.

\section{IV.CONSIDERAÇÕES FINAIS}

Optamos por encaminhar nossas considerações finais por meio de algumas questões. Qual o ponto a partir do qual a defesa do "regime que nos convém" tornou ou torna legítima a prática do golpe, ancorada, por sua vez, na práxis política de negação da capacidade dos votantes e, portanto, de negação da possibilidade de transformações qualitativas por meio do voto, da participação restrita ou da participação ampliada dos cidadãos e/ou de grupos sociais organizados? Ou, dito de outra maneira: até que ponto as dissensões e conflitos são apenas entendidos e expressos como um indício da baixeza da política, em visões que alinhavam perspectivas liberais e perspectivas autoritárias; e a partir de que ponto, diferentemente, tornam a força um recurso político "legítimo", quer dizer, tornam a intervenção de um agente "externo" ao campo da política um recurso freqüente, como foi o caso dos inúmeros episódios

\footnotetext{
11 Mais tarde, o jornal afirmaria que votos supostamente orientados por um partido ilegal, o Partido Comunista, teriam sido necessários para a vitória de Kubitschek, o que demonstraria a fraqueza do regime democrático no Brasil. Em momento de campanha aberta pelo golpe que impedisse a posse dos eleitos, um editorial diria ter sido o apoio comunista a Juscelino e Jango "uma demonstração irretorquível de que vêm faltando forças ao regime para defender-se, por meios normais, dos perigos que o cercam" (SONHO E REALIDADE, 1955, p. 3).
} 
nos quais os militares foram chamados por partidos e pela própria imprensa a assumir sua suposta responsabilidade diante dos conflitos e da projeção do caos político, tal como ocorreu durante a crise de 1955 ?

Procuramos indicar, neste texto, alguns aspectos do pensamento e da prática política que antecedeu o golpe civil-militar de 1964, da maneira como estiveram presentes nas páginas de dois jornais representativos daquele período. Ainda que nos tenhamos restringido, neste artigo, à crise de 1955, sustentamos a hipótese inicialmente explicitada de que as discussões aqui indicadas possam auxiliar na compreensão de um paradoxo presente nas memórias predominantes e em parte dos estudos históricos sobre o chamado período democrático situado entre a queda da ditadura do Estado Novo, em 1945, e o início de uma nova ditadura marcada, também ela, pelo arbítrio e pela violência. O paradoxo a que nos referimos implica a operação (estratégia?) freqüente de destacar e desligar os chamados anos dourados dos anos de chumbo que o sucederam, permitindo que as descontinuidades, sobrepostas às continuidades, ofusquem aspectos importantes das práticas e percepções que gestaram a ditadura posterior. Não estamos sugerindo que as descontinuidades devam ser esquecidas ou que não sejam relevantes, mas, sim, que as continuidades podem ser esclarecedoras no que se refere ao pensamento político no Brasil e, mais especificamente, às relações entre imprensa, liberalismo e autoritarismo - ou entre jornalismo, democracia e golpe no país, nos termos por que optamos no título deste artigo.

Inserindo-se nessa operação (ou estratégia), uma edição recente da Secretaria Municipal de Cultura do Rio de Janeiro, comemorativa dos 100 anos de fundação do Correio da Manhã, destacou a coragem e a liberdade oposicionistas daquele jornal, em detrimento de suas ações pró-golpe e de sua participação intensa na crise que levaria ao suicídio de Getúlio Vargas, em 1954. De modo semelhante, em 2000, quando o "Estadão" fez 125 anos, a edição comemorativa que citamos nas primeiras páginas deste texto apresentou uma breve história do jornal paulista por meio de uma narrativa que salta do combate ao Estado Novo ao combate à ditadura de 1964, da intervenção sofrida nos anos 1940 à presença de censores na redação do jornal no início dos anos 1970. O silêncio a respeito dos anos entre a derrocada de uma ditadura e o princípio de outra pode ser explicado, em parte, pela práxis destacada neste texto, ainda que tenhamos nos restringido à crise de 1955.

Em uma edição comemorativa anterior, mais próxima do momento para que nos voltamos, quando o Estado festejava seus 75 anos de existência, em janeiro de 1950, Júlio de Mesquita Filho ressaltava duas continuidades principais na história do jornal: 1) o fato de ter estado nas mãos de uma mesma família durante aproximadamente toda sua história (desde 1885) e 2) a perspectiva liberal, a defesa do liberalismo desde as campanhas republicanas da Província de S. Paulo até aqueles dias. Esta última linha de continuidade devia-se, segundo o proprietário e diretor do jornal, à crença de que seria ainda o liberalismo (não definido nesse texto, como em inúmeros outros, um conceito recorrente em sua imprecisão) que proporcionaria, ao mesmo tempo, o clima necessário ao desenvolvimento das liberdades humanas e às conquistas sociais. Na propagação desses ideais, aparecem juntos $O$ Estado de $S$. Paulo e a UDN, seja nas palavras de Júlio de Mesquita Filho, seja nas do então Presidente da UDN paulista, Waldemar Ferreira: "A União Democrática Nacional pode, hoje, orgulhar-se de ser o partido de maior prestígio na opinião pública. Por sua vez, O Estado de S. Paulo, que tanto se identifica com a gloriosa falange política, vem sendo neste momento, como nunca em sua história, prestigiado por essa mesma opinião. São fatos que se completam [...]" (FERREIRA, 1950).

Perguntamos, assim: o golpismo teria sido negador da tradição liberal ressaltada por Júlio de Mesquita Filho, justificando que 50 anos depois, ao comemorar 125 anos de existência, fosse necessário legar ao silêncio ou ao esquecimento parte de sua história, como em um lapso ocasional? Ou será que, para entendermos as premissas e as formas históricas assumidas pelas tradições políticas vinculadas ao liberalismo, devemos entender como delas constitutivas uma série de práticas que, aparentemente, seriam negadoras de seus pressupostos? Não se trataria, pois, de apontar para suas ambigüidades, mas de pensar no modo como essas práticas, assim como os discursos que procuraram funcionar como fontes eficazes para sua legitimação, compuseram - e ainda compõem, em certa medida - aspectos importantes para a compreensão das tradições do pensamento político 
"vencedoras" no Brasil, com atenção para os sentidos nelas assumidos pelo conceito de democracia e para os limites por elas atribuídos às práticas políticas democráticas em momentos históricos peculiares.

Como afirma Maria Vitória Benevides (1981), em estudo sobre a UDN, uma contradição em termos marcou o liberalismo udenista, em seu recurso repetido e persistente às soluções extra-legais e à intervenção dos militares na política. Poderíamos utilizar essa mesma observação em relação a $O$ Estado de S. Paulo. O jornal paulista de maior circulação durante o período, em seu conservadorismo, não deixou de afirmar, simultaneamente, suas raízes liberais e a opção por soluções extra-legais e pela mão salvadora dos militares, em momentos em que a situação política e social pareceu-lhe passível de transformações ou, em termos políticos, de permanências indesejáveis, como a do poder de Vargas e de seus aliados políticos

Esse parece-nos ter sido, mais do que um aspecto contraditório, um elemento constitutivo e central para a compreensão da ideologia liberal naquele período, para além das peculiaridades na história do jornal $O$ Estado de S. Paulo, isto é, permitindo hipóteses mais abrangentes. Os discursos aqui analisados, como indicamos, extrapolaram o terreno do liberalismo conservador ao qual procuraram vincular-se a UDN e $O$ Estado de S. Paulo, explicitando, ao mesmo tempo, os sentidos múltiplos assumidos pelo conceito de democracia na luta política e os limites do processo democrático como se constituiu naquele período.

De modo semelhante, a defesa do curso normal da democracia representativa, quando assumida pelos jornais analisados, não deixou de fundamentar-se em elementos constitutivos da práxis autoritária no país, por mais paradoxal que possa parecer. O exemplo principal, neste trabalho, foi indicado pelas formulações presentes nos artigos de Augusto Frederico Schmidt, publicados no Correio da Manhã.

Para utilizar o enunciado citado há pouco, "o regime que nos interessa", como demonstraram parcelas consideráveis das elites liberais conservadoras no Brasil em diversos momentos, deveria ser alcançado por meio da força ou de um interregno de suspensão das liberdades, para que vingasse, então, a verdadeira democracia: nada mais semelhante à tradição do "autoritarismo instrumental", tal como definida por Wanderley Guilherme dos Santos. Nada mais próximo, no entanto, no período estudado, da práxis de uma série de agentes políticos identificados como liberais. Encerramos o texto, portanto, indicando a necessidade de ultrapassar, no que se refere às análises aqui desenvolvidas e às pesquisas nas quais se fundaram - assim como à práxis política no período analisado, com destaque para a atuação dos veículos de imprensa que destacamos -, a oposição entre liberalismo e autoritarismo, a contraposição entre os sentidos assumidos pela democracia nos textos expostos e o golpismo, buscando, assim, compreender esses termos em suas sobreposições e entrelaçamentos.

Flávia Biroli (fbiroli@terra.com.br) é Doutora em História pela Universidade Estadual de Campinas (UNICAMP) e Professora do Instituto de Ciência Política da Universidade de Brasília (UnB).

\section{REFERÊNCIAS BIBLIOGRÁFICAS}

ABREU, A. A. \& LATTMAN-WELTMAN, F. 1994. Fechando o cerco : a imprensa e a crise de agosto de 1954. In : GOMES, A. C. (org.). Vargas e a crise dos anos 1950. Rio de Janeiro : Relume-Dumará.

ANDRADE, J. R. 1991. Um jornal assassinado a última batalha do Correio da Manhã. Rio de Janeiro : J. Olympio.
BENEVIDES, M. V. M. 1981. A UDN e o udenismo : ambigüidades do liberalismo brasileiro. 1945-1965. Rio de Janeiro: Paz e Terra.

BLOEM, R. 1955. A crise da democracia e a reforma eleitoral. São Paulo : Martins.

BRESCIANI, M. S. 2001. Identidades inconclusas no Brasil do século XX. Fundamentos de um lugar comum. In : BRESCIANI, M. S. 
\& NAXARA, M. (orgs.). Memória e res(sentimento). Campinas : UNICAMP.

BIROLI, F. 2003. Com a corrente : modernidade, democracia e seus sentidos no jornalismo brasileiro dos anos 1950. Campinas. Tese (Doutorado em História). Universidade Estadual de Campinas.

CARDOSO, M. L. 1978. Ideologia do desenvolvimento. Brasil : JK-JQ. $2^{\mathrm{a}}$ ed. Rio de Janeiro : Paz e Terra.

DOURADO, A. 2000. Gaiola aberta : tempos de JK e Schmidt. Rio de Janeiro : Rocco.

FERREIRA, W. 1950. O $75^{\circ}$ aniversário de $O$ Estado de S. Paulo. O Estado de S. Paulo, 5.jan.

KUCINSKI, B. 1975. Os cem anos de vida do jornal $O$ Estado de S. Paulo : liberal, conservador, antifascista. O Estado de S. Paulo, 3.jan, p. 4-5, sessão "Opinião".

LOCKE, J. 1983. Segundo tratado sobre o governo civil. $3^{\text {a }}$ ed. Col. "Os pensadores". São Paulo : Abril Cultural.

MARTINS, W. 1951. Introdução à democracia brasileira. Porto Alegre : Globo.

1955. A crise da democracia. $O$ Estado de S. Paulo, 18.ago., p. 8
SANTOS, W. G. 1978. A práxis liberal no Brasil : propostas para reflexão e pesquisa. In : Ordem burguesa e liberalismo político. São Paulo : Duas Cidades.

SCHMIDT, A. F. 1955a. Inatualidade política. Correio da Manhã, 3.ago., p. 2.

1955b. Saudades de um Brasil. Correio da Manhã, Rio de Janeiro, 11.ago., p. 2.

1955c. Um tempo novo. Correio da Ma$n h \tilde{a}$, Rio de Janeiro, 2.out., p. 2.

1955d. Tema inatual. Correio da Manhã, Rio de Janeiro, 17.nov., p. 2.

1964. Prelúdio à revolução. Rio de Janeiro : Val.

TARDE, G. 1992a. A opinião e a conversação. In :__. A opinião e as massas. São Paulo : M. Fontes.

1992b. O público e a multidão. In : A opinião e as massas. São Paulo : M. Fontes.

TOCQUEVILLE, A. 1998. A democracia na América. 2 v. São Paulo : M. Fontes.

VIANNA, O. 1930. Problemas de política objetiva. São Paulo : Nacional.

1949. Instituições políticas brasileiras. Rio de Janeiro : J. Olympio.

\section{OUTRASFONTES}

A crise da democracia. 1955. O Estado de S.Paulo, 18.ago., p. 8.

Correio da Manhã. Compromisso com a verdade. 2000. Cadernos de Comunicação. Série Memória. Rio de Janeiro : Secretaria Especial de Comunicação Social-Prefeitura do Rio de Janeiro.

Editorial. 1956. Correio da Manhã, Rio de Janeiro, 2.set., p. 6.
Na Câmara dos Deputados. 1955. O Estado de S.Paulo, 5.nov., p. 3.

O Estadão faz 125 anos, mas só conta 120.2000. $O$ Estado de S. Paulo, jan.

O nosso conselho. 1955. O Estado de S. Paulo, 28.set., p. 3.

Sonho e realidade. 1955. O Estado de S. Paulo, 8.out., p. 3.

Vigilância democrática. 1955. O Estado de S. Paulo, 25.set., p. 8 . 